\title{
Ethical Aspects of Social Media Use by Young Clergy
}

\author{
Thomas MJ \\ Ph.D. Scholar, Department of Psychology, Don Bosco University, Guwhati, Assam. \\ Corresponding Author : Thomas MJ \\ E-mail: mjtomssp@gmail.com
}

\begin{abstract}
The present paper looks at the growing problem of social media amongst the young clergy in India. Social media usage while potentially benefitting from a religious perspective may also serve as a distraction to young clergy from their religious duties and this may lead many of them spending large amounts of time on social media. The article outlines the need to restrict social media use in young clergy and delineates the ethical aspects of the same.
\end{abstract}

Key words: ethics, social media, young, young clergy

\section{INTRODUCTION}

Social Media is a term that is so often used in our daily conversations. Whether we like it or not, it has become an inevitable part of our life and it is going to stay that way in the time to come. Its rapid growth and acceptability has greatly influenced human behaviour, lifestyle and thinking. People regardless of their age, gender, status and geographical location actively get involved in different social networking sites. The speed, cost and reach captivates the users to spend more time on the social media. Whether social media is good or evil will depend on the nature of its use. Pope Francis, who called himself "a disaster" when it comes to technology said that the Internet, social networks and text messages are "a gift of God" if used wisely. Emails, text messages, social networks and chats can also be fully human forms of communication [1]. While acknowledging the tremendous growth of social media over the year, this article focuses its attention on some of the essential ethical aspects the young clergy should follow.

\section{WHAT IS SOCIAL MEDIA}

According to the Merriam-Webster dictionary online, Social Media is defined as "forms of electronic communication (as Web sites for social networking and microblogging) through which users create online communities to share information, ideas, personal messages, and other content (as videos)" [2].

The emergence of social media began almost at the advent of internet when people started to use this medium to share information and exchange communicate with each other. Although people in general tend to restrict social media to some networking websites like Facebook, WhatsApp and Twitter, social media in fact covers various services relating to content formation and sharing and exchange. This could include all types of internet forums, blogs, wikis, and podcasts among others [3].

\section{The Role of Social Media}

Social media empowers social change in the society. It provides a platform for people to air their thoughts and opinions and the possibility of being heard by others. Social media influences 
people from all walks of life including celebrities, politicians, public figures, businessmen and media tycoons in their decision making, interests and thought process [3].

Social media has undergone tremendous transformation over the years and it has brought about remarkable improvements in the lives of people. Even though initially it was meant to promote good values and common good, bad elements crept in as time passed by. It has now become a platform for anyone and everyone to post comments and opinions according to his/her wishes. Therefore, it is of vital importance that certain tools are employed and common guidelines are observed to ensure human dignity and accuracy of information.

Akin to the general population, the clergy too are passionate users of social media today. They use it to share information and to post comments and opinions on various topics. The chances are that they too will have equal stakes on both the benefits and ill-effects of the social media. Therefore, clergy must be disciplined users if they want to be credible members on the social media platform.

\section{CHURCH AND SOCIAL MEDIA}

Over the years, religious communication and activities have grown online and different religions like Christianity, Judaism, Islam, Buddhism, Hinduism, and Paganism have their online presence. Pew report [4] states that $64 \%$ (128 million) of U.S. internet users have done things online that related to religious or spiritual matters. This figure increased substantially with every successive reports. Pope John Paul II [5] exhorted the Church "to be bold and creative" in using the media. Pope Paul VI said, "The Church would feel guilty before the Lord if she did not utilize these powerful means" [6,no.45]. Church believes that creative use of social media can stir interest in individuals particularly the youth to actively participate in the liturgy and worship. Different social networking sites, particularly those custom designed for religious needs would help the members to stay engaged with their religious communities and neighbourhood.

\section{ETHICAL CONSIDERATIONS FOR YOUNG CLERGY}

The advancement in new information technologies cautions us with many ethical concerns in the social networking etiquette. While there are many advantages, we can't ignore the harm done to the society by the inappropriate use of the social media. Following considerations in the use of the social media might help young clergy to ensure that right values and morals are upheld and social media is primarily used for the spread of the Good News.

\section{Uphold Morals and Values}

With the revolution that internet and social media brings about in the modern society, the young clergy like the youth around is not left with the choice of whether or not to use social media, but only how to creatively and effectively participate in the social media in order to stay relevant in a fast evolving society. Since Church does not exist devoid of the society, she can't ignore the presence and impact of social media on her faithful and activities today. The clergy therefore should engage in social media, and do so to share information and opinions that are relevant andto uphold the values and morals of the Church. "The human person and the human community are the end and measure of the use of the media of social communication; communication should be by persons to person for the integral development of persons" $[7$, no.21].

\section{Respect for All}

Clergy has to respect the opinions of all. He has to show cultural sensitivity and esteem for others' values and beliefs. He has to guarantee that nothing unethical occurs while using the social media. It is to be reminded that social media is not a platform for anyone, particularly the clergy to engage in unhealthy arguments and mudslinging. Counter opinions are to be expressed with utmost care and with respect for the other. Clergy is a spokesperson of the Church and therefore be on guard while clarifying comments and airing opinions. Derogatory and defaming 
posts are to be avoided as any comment once posted becomes public and can spread like viral leading to serious damage to persons and legal problems. Even provocative comments are to be responded with kindness, compassion and prudence. Social media is not a platform to settle scores with the other, instead make it a pulpit where mutual respect and appreciation is maintained.

\section{Promote Common Good}

Second Vatican Council teaches that the freedom of speech for individuals and groups must be permitted so long as the common good and public morality be not endangered [8]. Social Media has to work towards personal fulfilment and life satisfaction of all members. The good of an individual member greatly depends upon the good of the group or the community one belongs. Clergy should care for one another and promote solidarity among members of social media. While everyone has the right to know the truth, everyone also has the responsibility to communicate the truth as these are important imperatives in promoting common good. Social media also contribute towards solving human problems, promoting integral development of members, sharing one another's burdens, realizing dreams, and creating a world governed by justice, peace and love. Clergy has to encourage the gifts and talents and promote positive attitude in others, and thus uphold social media as a true gift from God [9].

\section{Privacy and Confidentiality}

There is a tremendous amount of data on the social media and therefore there are privacy concerns attached to it [10].Every clergy is ordained primarily for the care of souls. That involves access to a lot of personal information through listening to the members. The clergy has the moral obligation to maintain the confidentiality of these data although it may not come under the seal of confession. People who follow the social networking sites know about the growing concern over breach of privacy and confidentiality. Anything that affects his professional credibility should be considered unethical. Or anyreference to persons or families or any attempt to draw out information that would some way damage the good name of any individual would be considered unethical invasion into the privacy of the person. Clergy has to keep guard not to leak out any personal information of members to the social media due to his negligence.

\section{Honesty and Truthfulness}

For all users of social media including the clergy has the duty to be honest and truthful about the content shared on the social networking sites. Moreover, clergy being a person with certain privileges and authority has the responsibility to share honest, authentic and appropriate information about the people and things on social media. People easily tend to believe and share the posts and comments of clergy. Any dishonest and false information is going to detrimentally affect the reputation and good name of oneself and others. Therefore, clergy has to keep the ethics in front while using the social media. They have to ensure to acknowledge the source and authenticity of information to avoid misdirection, intellectual theft and legal complications.

\section{CONCLUSIONS}

Every means of communication is a gift of God and the purpose is to promote good values, morals and thoughts. The challenging question for the young clergy of today is whether he is making the best use of this God-given gift, and what role does he play in promoting good and eliminating evil around him. Every clergy should work towards making social media a platform to promote common good, practice mutual respect and appreciation, honesty and truthfulness while ensuring the privacy and confidentiality of members. Social media can make an enormously valuable contribution to human life. It can foster prosperity and peace, intellectual and aesthetic growth, mutual understanding among peoples and nations on a global scale [11]. 


\section{REFERENCES}

1. Pope Francis. Reuters. 2016 January 22. Retrieved on 2018 January 9 from https://in.reuters.com/article/reuters-america-news-schedule-morning/reuters-americanews-plan-for-friday-jan-22-idINL2N15610Y

2. Merriam-Webster. 2017 December 31. Retrieved on 2018 January 8 from https://www.merriam-webster.com/dictionary/social\%20media

3. Taprial V, Kanwar P. Understanding Social Media. Bookboon; 2012.

4. Hoover SM, Clark LS, Rainie L. Faith online. Pew Internet \& American Life Project. 2004. Retrieved on 2017 November 27 from http://www.pewinternet.org/files/oldmedia/Files/Reports/2004/PIP_Faith_Online_2004.pdf

5. Pope John Paul II. 2000 June 4. Proclaiming Christ in the Media at the Dawn of the New Millennium. Retrieved on 2017 December 14 from http://w2.vatican.va/content/john-paulii/en/messages/communications/documents/hf_jp-ii_mes_20000124_worldcommunications-day.html

6. Pope Paul VI. 1975 December 8. EvangeliiNuntiandi. Retrieved on 14 December 2017 from http://w2.vatican.va/content/paul-vi/en/apost_exhortations/documents/hf_pvi_exh_19751208_evangelii-nuntiandi.html

7. Foley JP. 2000 June 4. Ethics in Communications. Retrieved on 2018 January 7 from http://www.vatican.va/roman_curia/pontifical_councils/pccs/documents/rc_pc_pccs_doc_ 20000530_ethics-communications_en.html

8. Pope Paul VI. 1965 December 7. Gaudiumetspes. Retrieved on 2018 January 6 from http://www.vatican.va/archive/hist_councils/ii_vatican_council/documents/vatii_const_19651207_gaudium-et-spes_en.html

9. John Paul II.2001 January 6. Novo millennioineunte. Retrieved on 2018 January 10 from http://w2.vatican.va/content/john-paul-ii/en/apost_letters/2001/documents/hf_jpii_apl_20010106_novo-millennio-ineunte.html

10. Kizza JM. Ethical and Social Issues in the Information Age. $6^{\text {th }}$ ed. London: Springer; 2017.

11. Foley JP. 2002 February 22. Ethics in Internet. Retrieved on 2018 January 10 from http://www.vatican.va/roman_curia/pontifical_councils/pccs/documents/rc_pc_pccs_doc_ 20020228_ethics-internet_en.html

Acknowledgements - Nil

Source of Funding - Nil

Conflict of Interest - Nil 